\title{
MYRMECOFAUNA (HYMENOPTERA: FORMICIDAE) AS A BIOINDICATOR OF THE QUALITY OF SOILS SUBMITTED TO THE APPLICATION OF PIG FARMING WASTEWATER
}

\author{
Myrmecofauna (Hymenoptera: Formicidae) como bioindicador da qualidade dos solos submetidos à aplicação da água \\ residuária da suinocultura
}

\author{
Dinéia Tessaro $^{1 *}$; Silvio Cesar Sampaio ${ }^{2}$; Elisandra Pocojeski ${ }^{3}$ \\ 1Professor; Doutor em Engenharia Agrícola; Universidade Tecnológica Federal do Paraná - Campus Dois Vizinhos; e-mail: \\ dtessaro@utfpr.edu.br \\ *Autor para correspondência \\ ${ }^{2}$ Professor; Doutor em Engenharia Agrícola; Universidade Estadual do Oeste do Paraná - Campus Cascavel; e-mail: \\ silvio.sampaio@unioeste.br \\ 3Professor; Doutor em Ciência do Solo; Universidade Tecnológica Federal do Paraná - Campus Dois Vizinhos; e-mail: \\ elisandrap@utfpr.edu.br
}

Artigo enviado em 30/06/2017, aceito em 24/11/2017 e publicado em 20/12/2017.

\begin{abstract}
The structure of ant communities is of particular interest as a bioindicator, given their importance in environmental impact studies, as they present abundance and species richness, specialized taxa, wide geographical distribution, and are easily sampled, in addition to being sensitive to environmental changes. Therefore, the objective of this study was to evaluate the effects of wastewater application $\left(0,100,200\right.$, and $\left.300 \mathrm{~m}^{3} \mathrm{ha}^{-1}\right)$ combined with nitrogen fertilization ( 0 and $100 \%$ of the recommended dose for the crop) on the myrmecofauna in plantations of minimilho in the municipality of Cascavel, PR. To evaluate the myrmecofauna, pitfall traps were installed and organisms were classified by gender. The Formicidae family exhibited increased density up to $200 \mathrm{~m}^{3} \mathrm{ha}^{-1}$ doses of pig farming wastewater, but no changes were observed in response to chemical fertilization. However, when sorted by gender at the taxonomic level, no significant effects were observed on the different groups, except for the Solenopsis genus following the use of 0 or $300 \mathrm{~m}^{3} \mathrm{ha}^{-1}$ pig farming wastewater.
\end{abstract}

Keywords - edaphic fauna, edaphic ants, water reuse in agriculture.

Resumo - A estrutura das comunidades de formigas é de particular interesse como bioindicadoras dada sua importância em estudos de impacto ambiental, uma vez que apresentam abundância e riqueza de espécies, táxons especializados, ampla distribuição geográfica, facilmente amostrada, além de serem sensíveis às mudanças ambientais. Considerando o exposto $\mathrm{O}$ objetivo do trabalho foi avaliar os efeitos da aplicação de água residuária da suinocultura $\left(0,100,200\right.$ e $\left.330 \mathrm{~m}^{3} \mathrm{ha}^{-1}\right)$ combinada com adubação nitrogenada ( 0 e $100 \%$ da dose recomendada para a cultura) sobre a mirmecofauna em plantações de minimilho no município de Cascavel - PR.”. Para a avaliação da mirmecofauna, foram instaladas armadilhas de queda sendo os organismos classificados ao nível de gênero. A família Formicidae teve densidade aumentada até a dose $200 \mathrm{~m}^{3} \mathrm{ha}^{-1}$ de água residuária da suinocultura, contudo sem mostrar alterações decorrentes da adubação química. No entanto, a classificação ao nível taxonômico de gênero demonstrou não existir efeitos significativos sobre os diferentes grupos, exceto para o gênero Solenopsis, quando utilizadas as doses de 0 e $300 \mathrm{~m}^{3}$ ha $^{-1}$ de água residuária da suinocultura.

Palavras-chave - fauna edáfica, formigas edáficas, reuso de água na agricultura. 


\section{INTRODUCTION}

Brazil displays indicators in pig farming of high productivity in advanced technology, and is positioned among the top countries for increasing pig production. This is because Brazil possesses state-ofthe-art technology in all areas of pig production: genetics, nutrition, sanitation, management, facilities, and equipment. (ABCS, 2011; 2016). However, high production per unit area leads to the accumulation of effluents in the properties, which in most cases, exceed the agricultural area required to absorb the production waste (SEGANFREDO, SOARES and KLEIN, 2003). Under this scenario, environmental agencies have shown great concern, since when the soil bearing capacity is exhausted, this waste can cause a large amount of environmental damage (SEIDEL et al., 2010). In this regard, studies investigating water reuse in the environment have gained importance, and are usually related to physical-chemical changes in the soil (CAMPOS et al., 2012; LUCAS et al., 2013; MENEGHETTI et al., 2013; KESSLER et al., 2013; KESSLER et al., 2014; MAFRA et al., 2014), contamination of surface and groundwater (MAGGI et al,. 2011; BOLZANI, OLIVEIRA and LAUTENSCHLAGER 2012; MAGGI et al., 2013; CAPOANE et al., 2015), and the contribution to crop productivity (MENEGHETTI et al., 2012; CAMPOS et al., 2013). Only recently have efforts been increased in studies on soil biology, especially those focused on meso and macrofauna (ALVES et al., 2008; TESSARO et al., 2011; TESSARO et al, 2013; CASTALDELLI et al., 2015: SILVA et al., 2016).

The addition of organic residues can influence soil biota, since they act as a food source and modify soil temperature and coverage In addition, they contain toxic substances and harmful heavy metals, which adversely affect the fauna (BARETTA et al., 2003; MELO 2006). In this regard, the need to identify and quantify the disturbances caused by human activities in diverse environments has attracted the attention of researchers searching for organisms that can monitor the degree of ecosystem integrity. Therefore, several studies have shown that ants have potential for use as bioindicators of environmental quality, in natural or altered areas (RIBAS et al., 2012a). Ants have been studied in various types of environments and situations, such as areas subjected to burning (BOSCARDIN et al., 2014); contaminated areas (RIBAS et al., 2012c); agroforestry systems and agroecosystems (GONZÁLEZ-VALDIVIA et al., 2013; RAMÍREZ et al., 2012); crop-livestock systems (CREPALDI et al., 2014); agricultural crops (COUTO et al, 2010); in the rehabilitation of mined areas and degraded areas (ROSADO et al., 2014, RIBAS et al., 2012b, ROCHA et al., 2015); in revegetation of riparian areas (GOLLAN et al., 2011); and in forest disturbances (LEAL et al,. 2012; MIRANDA et al., 2013). Such potential is due to the high abundance and species richness of these specialized groups, their wide geographical distribution, sampling facilities, and their sensitivity to changes in environmental conditions (HOFFMANN and ANDERSEN, 2003). Ants are distributed in 327 genera and 16 subfamilies, and 13,188 species exist (BOLTON, 2016). Of these, 119 genera are found in the Neotropical region, belonging to eight subfamilies, with about 3,100 described species (FERNÁNDEZ and OSPINA, 2003).

Based on the above, coupled with the lack of information on ants in relation to organic fertilization, this study aimed to evaluate the effect of pig farming wastewater (PFW) application combined with chemical fertilization on the density and diversity of myrmecofauna in typic dystroferric Red Latosol cultivated with baby corn in a subtropical region.

\section{MATERIAL AND METHODS}

This study was conducted in Cascavel, PR, Brazil (24 48 'S and $5326^{\prime} \mathrm{W}$ ), at an altitude of $760 \mathrm{~m}$. The weather is humid subtropical (Cfa), with an average annual rainfall of $1,800 \mathrm{~mm}$, hot summers, infrequent frosts, and a tendency for rainfall to be concentrated in the summer months; however, there is no definite dry season. The average temperature is $20^{\circ} \mathrm{C}$ and average relative humidity is $75 \%$. The soil of the area studied is a typic dystroferric Red Latosol with clayey texture (EMBRAPA, 2006), which, since 2006, has received nutrients from the application of PFW and nitrogen fertilization (NFR). Notably, the treatments used in this study have been consistent since 2006, ensuring a track record of 3 years of PFW application combined with NFR for each treatment.

At the beginning of the current study, the soil was chemically characterized before treatments were applied; the results are shown in Table 1.

The PFW was collected in an integrated bio system composed of a bio digester followed by a sedimentation tank and stabilization pond., Chemical characterization was performed according to the methodology of Apha et al. (1998) (Table 2). 
Table 1. Chemical characterization of experimental parcels before application of wastewater and nitrogen fertilization

\begin{tabular}{|c|c|c|c|c|c|c|}
\hline \multirow{3}{*}{ Attribute } & \multicolumn{6}{|c|}{ Treatment } \\
\hline & \multicolumn{2}{|c|}{ NFR } & \multicolumn{4}{|c|}{ PFW } \\
\hline & 0 & 100 & 0 & 100 & 200 & 300 \\
\hline Sodium $\left(\mathrm{mg} \mathrm{dm}^{-3}\right)$ & 2.91 & 2.50 & 2.66 & 2.50 & 3.00 & 2.66 \\
\hline Calcium $\left(\mathrm{cmol}_{\mathrm{c}} \mathrm{dm}^{-3}\right)$ & 5.85 & 5.81 & 5.86 & 6.24 & 5.36 & 5.87 \\
\hline Magnesium $\left(\mathrm{cmol}_{\mathrm{c}} \mathrm{dm}^{-3}\right)$ & 3.71 & 3.45 & 3.71 & 3.69 & 3.30 & 3.63 \\
\hline Potassium $\left(\mathrm{cmol}_{\mathrm{c}} \mathrm{dm}^{-3}\right)$ & 0.35 & 0.45 & 0.22 & 0.30 & 0.49 & 0.59 \\
\hline $\mathrm{H}+\mathrm{Al}\left(\mathrm{cmol}_{\mathrm{c}} \mathrm{dm}^{-3}\right)$ & 2.72 & 2.66 & 2.72 & 2.42 & 3.02 & 2.58 \\
\hline Sum of bases $\left(\mathrm{cmol}_{\mathrm{c}} \mathrm{dm}^{-3}\right)$ & 9.93 & 9.72 & 9.82 & 10.24 & 9.16 & 10.10 \\
\hline CTC pH 7,0 $\left(\mathrm{cmol}_{\mathrm{c}} \mathrm{dm}^{-3}\right)$ & 12.66 & 12.39 & 12.55 & 12.66 & 12.22 & 12.68 \\
\hline Organic Carbon $\left(\mathrm{g} \mathrm{dm}^{-3}\right)$ & 12.67 & 11.50 & 11.80 & 12.04 & 12.11 & 12.39 \\
\hline Organic matter $\left(\mathrm{g} \mathrm{dm}^{-3}\right)$ & 19.78 & 21.78 & 20.31 & 20.72 & 20.83 & 21.31 \\
\hline Sat. Bases $(\%)$ & 72.06 & 77.88 & 77.32 & 80.64 & 74.36 & 67.56 \\
\hline Phosphorus (mg dm${ }^{-3}$ ) & 8.68 & 13.77 & 8.87 & 11.63 & 14.21 & 8.87 \\
\hline Iron $\left(\mathrm{mg} \mathrm{dm}^{-3}\right)$ & 96.69 & 99.35 & 105.21 & 96.74 & 83.38 & 106.75 \\
\hline Manganese $\left(\mathrm{mg} \mathrm{dm}^{-3}\right)$ & 62.16 & 62.52 & 60.47 & 63.91 & 61.07 & 63.91 \\
\hline Copper $\left(\mathrm{mg} \mathrm{dm}^{-3}\right)$ & 10.72 & 10.49 & 10.39 & 10.31 & 10.80 & 10.93 \\
\hline $\operatorname{Zinc}\left(\mathrm{mg} \mathrm{dm}^{-3}\right)$ & 2.21 & 2.96 & 2.02 & 2.87 & 3.60 & 3.85 \\
\hline $\mathrm{pH}$ & 6.48 & 6.55 & 6.55 & 6.61 & 6.36 & 6.55 \\
\hline Dry mass $\left(\mathrm{kg} \mathrm{h}^{-1}\right)$ & 57.00 & 62.31 & 44.81 & 61.32 & 62.56 & 69.87 \\
\hline
\end{tabular}

*PFW: pig farming wastewater $\left(0,100,200\right.$, and $300 \mathrm{~m}^{3}$ in the baby corn crop cycle); NFR: nitrogen fertilization $(0$ - without addition of NFR; 100 - NFR dose recommended for the crop - $80 \mathrm{~kg} \mathrm{ha}^{-1}$ )

Table 2. Chemical characterization of pig farming wastewater.

\begin{tabular}{|c|c|}
\hline Attribute & Result \\
\hline $\mathrm{pH}\left(\mathrm{CaCl}_{2}\right)$ & 7.9 \\
\hline Electrical conductivity $\left(\mathrm{dS} \mathrm{m}^{-1}\right)$ & 2.1 \\
\hline Turbidity (NTU) & 278 \\
\hline $\mathrm{DBO}\left(\mathrm{mg} \mathrm{L}^{-1}\right)$ & 550 \\
\hline DQO $\left(\mathrm{mg} \mathrm{L}^{-1}\right)$ & 1450 \\
\hline Total Nitrogen $\left(\mathrm{mg} \mathrm{L}^{-1}\right)$ & 338.8 \\
\hline $\mathrm{N}-\mathrm{Nitrate}\left(\mathrm{mg} \mathrm{L}^{-1}\right)$ & 0.40 \\
\hline $\mathrm{N}$-Nitrite $\left(\mathrm{mg} \mathrm{L}^{-1}\right)$ & 8.00 \\
\hline Total Phosphorus (mg L ${ }^{-1}$ ) & 211.9 \\
\hline Potassium $\left(\mathrm{mg} \mathrm{L}^{-1}\right)$ & 440.0 \\
\hline Sodium $\left(\mathrm{mg} \mathrm{L}^{-1}\right)$ & 17.0 \\
\hline Calcium (mg L-1) & 2.25 \\
\hline Iron $\left(\mathrm{mg} \mathrm{L}^{-1}\right)$ & 75.0 \\
\hline Magnesium (mg L-1) & 0.95 \\
\hline Manganese (mg L-1) & 16.5 \\
\hline Copper $\left(\mathrm{mg} \mathrm{L}^{-1}\right)$ & 12.5 \\
\hline Zinc $\left(\mathrm{mg} \mathrm{L}^{-1}\right)$ & 76.5 \\
\hline Totals $\left(\mathrm{mg} \mathrm{L}^{-1}\right)$ & 1481 \\
\hline Stationary Totals $\left(\mathrm{mg} \mathrm{L}^{-1}\right)$ & 729.0 \\
\hline Volatile Totals (mg L-1) & 671.0 \\
\hline
\end{tabular}

PFW was applied in a single step, 7 days before the sowing of baby corn, was sown on the remains of oat culture. The variety BR 106, which has an approximate cycle of 80 days, was sowed manually by direct seeding, providing a stand of 180,000 plants $\mathrm{ha}^{-1}$. Given the needs of baby corn crop, which are based on those of corn, NFR was applied at a dose of $80 \mathrm{~kg} \mathrm{ha}^{-1}$ nitrogen in the form of urea. Fertilization 
was performed in two stages, by applying $30 \%$ of the recommended dose at sowing, and the remaining during the stage of development characterized by three to four developed leaves.

The edaphic myrmecofauna was sampled using pitfall traps installed in each experimental parcel; traps comprised flasks with a $6-\mathrm{cm}$ diameter, buried in the ground, with the hollow end level with the soil surface Preservative solution $(200 \mathrm{~mL})$ of $4 \%$ formaldehyde was placed in the traps. Samples were collected at three different times: 7 days after sowing (DAS), at the 15th leaf stage (41 DAS), and after the development of spikelets (72 DAS). In each collection, the traps remained in the field for 7 days and their contents were identified in the laboratory to the taxonomic level of genus, using a binocular magnifying glass and dichotomous keys for classification as detailed by Baccaro (2006) and Bolton (1994). Ant density, expressed as the population size, was estimated by converting the number of individuals per trap/day.

For each treatment, data were submitted to analysis of variance using the randomized blocks experimental design, in a $2 \times 4$ factorial design (two levels of fertilization, 0 and $80 \mathrm{~kg} / \mathrm{ha}$ of N-urea, and four doses of PFW, 0, 100, 200, and $300 \mathrm{~m}^{3} \mathrm{ha}^{-1}$ ) for a total of eight treatments performed in triplicate.

When necessary, the mathematical model was transformed $(y=x 0.5+0.5)$ to normalize the data, using the Open Source Software SISVAR, version 4.2 (Ferreira 2003), adopting the $F$ test at $p<0.05$, followed by the Scott-Knott test at 5\%.

\section{RESULTS AND DISCUSSION}

Table 3 shows the results of the test comparing the mean ant density in the three study periods.

Table 3. Average ant density of the Formicidae family (bodies/trap/day), collected on the, by treatment applied and timepoint.

\begin{tabular}{|c|c|c|c|c|c|}
\hline \multicolumn{6}{|c|}{ Treatment } \\
\hline \multicolumn{2}{|c|}{ NFR $(\%)$} & \multicolumn{4}{|c|}{ PFW $\left(\mathrm{m}^{3} \mathrm{ha}^{-1}\right)$} \\
\hline 0 & 100 & 0 & 100 & 200 & 300 \\
\hline \multicolumn{6}{|c|}{ First collection -7 DAS } \\
\hline $3,54 \mathrm{~A}$ & $4,13 \mathrm{~A}$ & $4,16 \mathrm{~A}$ & $3,21 \mathrm{~A}$ & $5,26 \mathrm{~A}$ & $2,97 \mathrm{~A}$ \\
\hline \multicolumn{6}{|c|}{ Second collection - 41 DAS } \\
\hline $3,86 \mathrm{~A}$ & $3,19 \mathrm{~A}$ & $2,54 \mathrm{~A}$ & $2,80 \mathrm{~A}$ & $6,14 \mathrm{~B}$ & $2,61 \mathrm{~A}$ \\
\hline \multicolumn{6}{|c|}{ Third collection -72 DAS } \\
\hline $3,22 \mathrm{~A}$ & $2,26 \mathrm{~A}$ & $1,69 \mathrm{~A}$ & $2,57 \mathrm{~A}$ & $4,35 \mathrm{~B}$ & $2,35 \mathrm{~A}$ \\
\hline
\end{tabular}

Knott test at $5 \%$ probability.

The density of organisms belonging to the Formicidae family was influenced by the use of wastewater, and was highest with the $200 \mathrm{~m}^{3} \mathrm{ha}^{-1}$ dose at 41 and 72 DAS compared with the other treatments.

Ants are the dominant taxonomic group in most ecosystems, and are present in various habitats. According to Marinho et al. (2002) and Andersen et al. (2002), ants are regarded as a suitable bioindicator in areas that have been subjected to human actions, such as soil management, industrial pollution, and the successful rehabilitation of degraded areas, because of the strong association between the state of vegetation, soil, and decomposition. Some group characteristics guarantee them, generally, this status, such as their high abundance, species richness, ease of sampling, separation into morpho-species, and the existence of specialized taxa that can perceive environmental changes (SILVA and BRANDÃO 1999). The results (Table 3 ) show that initially (at 7 DAS), there were no differences between the doses of PFW, probably because of the high mobility group and the similar quality of food between areas analyzed without developed vegetation. According to Schmidt, Ribas, Schoereder (2013), reduced vegetation cover can distinctly affect different myrmecofauna groups, with negative effects on specialist species in closed and cooler areas, and positive effects on specialized species in more open and warmer areas. Oliveira et al. (2011), also described the important role of vegetation on these organisms, noting that increased complexity of the vegetation contributes to greater diversity and group density. 
However, from the second collection, the predilection of the group treated with $200 \mathrm{~m}^{3} \mathrm{ha}^{-1}$ was visible, with a gradual increase in density observed as the PFW dose increased up to $200 \mathrm{~m}^{3} \mathrm{ha}^{-1}$. However, a decrease in the density of the group was observed with $300 \mathrm{~m}^{3} \mathrm{ha}^{-1}$, with levels very close to those reported with $0 \mathrm{~m}^{3} \mathrm{ha}^{-1}$.

The results also showed that over time (41 DAS), there was a decrease in the density of these organisms. This suggests that the systematic use of PFW under the evaluated conditions can lead to reduced populations of local myrmecofauna. This result is consistent with the findings of Alves et al. (2008), whom, when using pig slurry stored in dunghill for stabilization, observed that the myrmecofauna behaved in the same way at similar doses. Another factor that may have contributed to this reduction in the present study was the long dry season (30 days), which coincided with the evaluation period up to 72 DAS.

Taken together, these results suggest that, within certain limits (up to $200 \mathrm{~m}^{3} \mathrm{ha}^{-1}$ ), the use of effluents with the studied characteristics enhance soil conditions for myrmecofauna; however, it becomes a limiting factor at higher doses.

The response observed here is important, because the structure of ant communities is critical in studies investigating environmental impacts, since they maintain and restore soil quality, and act to redistribute particles, nutrients, and organic matter, thus improving water infiltration into the soil, due to its increased porosity and aeration (LOBRY DE BRUYN, 1999).

There were no significant differences in NFR between the periods analyzed, suggesting that the use of nitrogen fertilizers in the doses applied here does not alter the population density of these organisms.

Table 4 compares the mean ant density for each subfamily and genus identified.

In the three samples (Table 4), ants were captured that belonged to five of the 14 subfamilies found in Brazil (Ponerinae, Formicinae, Dolichoderinae, Ecitoninae, and Myrmicinae) (Bolton 2003), and to 16 distinct genera, with the highest number of collected genera from the subfamily Myrmicinae. The predominance of this subfamily could be explained by their high natural abundance and for being a group of ants their remarkable adaptability to many different ecological niches in the Neotropics (FOWLER et al., 1991). The dominance of this subfamily has also been reported in studies conducted in other types of crops, such as those by Couto et al., (2010) in growing soybeans, Santos, Carrano-Moreira and Torres (2012) in sugarcane, and Costa, Campos and Margarido (2014) in the cultivation and management of green manure.

It was also noted that in the three periods evaluated, the Dolichoderinae subfamily, Dorymyrmex genus, were present at the highest density compared with the other subfamilies, although this tendency was not statistically significant. According to Macedo (2004), this genus may occur in high abundance because these ants reduce the number of native ants close to their nests; they are very aggressive and can monopolize food sources, because of the strength of the recruited workers. This aggressive behavior may result in the emergence of other, mainly phytophagous insects, over the long term, since belonging to this genus can means the removal of predatory species from the environment.

Among the species of ants found of the Myrmicinae, the presence of the Acromyrmex genus in the first sampling period was notable. This group is characterized by species of leaf-cutting ants (Lacau et al., 2008), which are considered pests in agriculture, as they use fresh leaves, shoots, and flowers as substrates for fungal cultivation (HÖLLDOBLER and WILSON 1990). Considering its negative potential relative to plant growth, the occurrence of this group is undesirable in agricultural systems. Because of its occurrence during the first sampling period, it is possible that this group was inhibited by the application of nitrogen and PFW, making this a viable practice. However, further studies evaluating this genus in response to these parameters are needed.

The results of the first sampling did not reveal any differences in the density of ants between genera in any of the factors assessed. According to Wink et al. (2005), this reflects the low quality of food in the soil and organic matter, because under this initial condition, no differences in vegetation cover were observed. However, small variations were observed regarding the number of genera found under the different treatments. Of the 14 genera found at 7 DAS with the 0 NFR treatment, 12 were reported with the $100 \%$ NFR dose ( $80 \mathrm{~kg} \mathrm{ha}^{-1}$ of $\mathrm{N}$-urea) and with doses of 0 and $200 \mathrm{~m}^{3} \mathrm{ha}^{-1}$, while 11 genera were found with the 100 and $300 \mathrm{~m}^{3} \mathrm{ha}^{-1}$ doses. However, these results do not necessarily indicate a preference of the groups under different treatments, and may be related to the high mobility of the groups moving from one area to another (CORDEIRO et al., 2004). 
Table 4. Average density of edaphic ants in all genera (genus/trap/day) collected in pitfall traps following treatment with different doses of PFW and NFR in the three samples.

\begin{tabular}{|c|c|c|c|c|c|c|c|}
\hline \multirow[b]{3}{*}{ Subfamily } & \multirow[b]{3}{*}{ Genus } & \multicolumn{6}{|c|}{ Treatment } \\
\hline & & \multicolumn{2}{|l|}{ AND } & \multicolumn{2}{|c|}{ PFW } & \multirow[b]{2}{*}{200} & \multirow[b]{2}{*}{300} \\
\hline & & 0 & 100 & 0 & 100 & & \\
\hline \multicolumn{8}{|c|}{ First Collection -7 DAS } \\
\hline \multirow[t]{2}{*}{ Ponerinae } & Hypoponera & $0.32 \mathrm{~A}$ & $0.28 \mathrm{~A}$ & $0.28 \mathrm{~A}$ & $0.28 \mathrm{~A}$ & $0.33 \mathrm{~A}$ & $0.30 \mathrm{~A}$ \\
\hline & Pachycondyla & $0.11 \mathrm{~A}$ & $0.09 \mathrm{~A}$ & $0.16 \mathrm{~A}$ & $0.14 \mathrm{~A}$ & $0.04 \mathrm{~A}$ & $0.07 \mathrm{~A}$ \\
\hline Formicinae & Camponotus & $0.13 \mathrm{~A}$ & $0.09 \mathrm{~A}$ & $0.21 \mathrm{~A}$ & $0.02 \mathrm{~A}$ & $0.16 \mathrm{~A}$ & $0.04 \mathrm{~A}$ \\
\hline \multirow[t]{3}{*}{ Dolichoderinae } & Dorymyrmex & $0.73 \mathrm{~A}$ & $0.88 \mathrm{~A}$ & $0.73 \mathrm{~A}$ & $0.95 \mathrm{~A}$ & $0.76 \mathrm{~A}$ & $0.78 \mathrm{~A}$ \\
\hline & Tapinoma & $0.11 \mathrm{~A}$ & $0.14 \mathrm{~A}$ & $0.00 \mathrm{~A}$ & $0.02 \mathrm{~A}$ & $0.42 \mathrm{~A}$ & $0.07 \mathrm{~A}$ \\
\hline & Dolichoderus & $0.21 \mathrm{~A}$ & $0.36 \mathrm{~A}$ & $0.33 \mathrm{~A}$ & $0.02 \mathrm{~A}$ & $0.57 \mathrm{~A}$ & $0.23 \mathrm{~A}$ \\
\hline \multirow[t]{2}{*}{ Ecitoninae } & Nomamyrmex & $0.20 \mathrm{~A}$ & $0.67 \mathrm{~A}$ & $0.38 \mathrm{~A}$ & $0.09 \mathrm{~A}$ & $1.14 \mathrm{~A}$ & $0.14 \mathrm{~A}$ \\
\hline & Neivamyrmex & $0.36 \mathrm{~A}$ & $0.39 \mathrm{~A}$ & $0.40 \mathrm{~A}$ & $0.38 \mathrm{~A}$ & $0.52 \mathrm{~A}$ & $0.21 \mathrm{~A}$ \\
\hline \multirow[t]{6}{*}{ Myrmicinae } & Solenopsis & $0.61 \mathrm{~A}$ & $0.58 \mathrm{~A}$ & $0.33 \mathrm{~A}$ & $0.71 \mathrm{~A}$ & $0.76 \mathrm{~A}$ & $0.59 \mathrm{~A}$ \\
\hline & Pheidole & $0.03 \mathrm{~A}$ & $0.00 \mathrm{~A}$ & $0.00 \mathrm{~A}$ & $0.00 \mathrm{~A}$ & $0.00 \mathrm{~A}$ & $0.07 \mathrm{~A}$ \\
\hline & Atta & $0.05 \mathrm{~A}$ & $0.00 \mathrm{~A}$ & $0.11 \mathrm{~A}$ & $0.00 \mathrm{~A}$ & $0.00 \mathrm{~A}$ & $0.00 \mathrm{~A}$ \\
\hline & Olygomyermex & $0.22 \mathrm{~A}$ & $0.34 \mathrm{~A}$ & $0.38 \mathrm{~A}$ & $0,14 \mathrm{~A}$ & $0.40 \mathrm{~A}$ & $0.21 \mathrm{~A}$ \\
\hline & Acromyrmex & $0.09 \mathrm{~A}$ & $0.02 \mathrm{~A}$ & $0.11 \mathrm{~A}$ & $0.00 \mathrm{~A}$ & $0.11 \mathrm{~A}$ & $0.00 \mathrm{~A}$ \\
\hline & Cephalotes & $0.03 \mathrm{~A}$ & $0.08 \mathrm{~A}$ & $0.07 \mathrm{~A}$ & $0.09 \mathrm{~A}$ & $0.07 \mathrm{~A}$ & $0,00 \mathrm{~A}$ \\
\hline \multicolumn{8}{|c|}{ Second Collection - 41 DAS } \\
\hline \multirow[t]{2}{*}{ Ponerinae } & Hypoponera & $0.29 \mathrm{~A}$ & $0.35 \mathrm{~A}$ & $0.54 \mathrm{~A}$ & $0.35 \mathrm{~A}$ & $0.21 \mathrm{~A}$ & $0.19 \mathrm{~A}$ \\
\hline & Pachycondyla & $0.10 \mathrm{~A}$ & $0.15 \mathrm{~A}$ & $0.14 \mathrm{~A}$ & $0.14 \mathrm{~A}$ & $0.07 \mathrm{~A}$ & $0.16 \mathrm{~A}$ \\
\hline \multirow[t]{2}{*}{ Formicinae } & Camponotus & $0.03 \mathrm{~A}$ & $0.00 \mathrm{~A}$ & $0.07 \mathrm{~A}$ & $0.00 \mathrm{~A}$ & $0.00 \mathrm{~A}$ & $0.00 \mathrm{~A}$ \\
\hline & Brachymyrmex & $0.01 \mathrm{~A}$ & $0.01 \mathrm{~A}$ & $0.00 \mathrm{~A}$ & $0.00 \mathrm{~A}$ & $0.00 \mathrm{~A}$ & $0.04 \mathrm{~A}$ \\
\hline \multirow[t]{3}{*}{ Dolichoderinae } & Dorymyrmex & $0.96 \mathrm{~A}$ & $0.71 \mathrm{~A}$ & $0.69 \mathrm{~A}$ & $1.09 \mathrm{~A}$ & $0.69 \mathrm{~A}$ & $0.88 \mathrm{~A}$ \\
\hline & Tapinoma & $0.16 \mathrm{~A}$ & $0.08 \mathrm{~A}$ & $0.07 \mathrm{~A}$ & $0.26 \mathrm{~A}$ & $0.09 \mathrm{~A}$ & $0.07 \mathrm{~A}$ \\
\hline & Dolichoderus & $0.05 \mathrm{~A}$ & $0.05 \mathrm{~A}$ & $0.07 \mathrm{~A}$ & $0.14 \mathrm{~A}$ & $0.00 \mathrm{~A}$ & $0.02 \mathrm{~A}$ \\
\hline \multirow[t]{3}{*}{ Ecitoninae } & Nomamyrmex & $0.13 \mathrm{~A}$ & $0.03 \mathrm{~A}$ & $0.02 \mathrm{~A}$ & $0.04 \mathrm{~A}$ & $0.26 \mathrm{~A}$ & $0.00 \mathrm{~A}$ \\
\hline & Neivamyrmex & $0.40 \mathrm{~A}$ & $0.19 \mathrm{~A}$ & $0.19 \mathrm{~A}$ & $0.14 \mathrm{~A}$ & $0.69 \mathrm{~A}$ & $0.16 \mathrm{~A}$ \\
\hline & Eciton & $0.02 \mathrm{~A}$ & $0.05 \mathrm{~A}$ & $0.02 \mathrm{~A}$ & $0.00 \mathrm{~A}$ & $0.11 \mathrm{~A}$ & $0.02 \mathrm{~A}$ \\
\hline \multirow[t]{4}{*}{ Myrmicinae } & Solenopsis & $0.63 \mathrm{~A}$ & $0.70 \mathrm{~A}$ & $0.49 \mathrm{~B}$ & $0.28 \mathrm{~A}$ & $0.54 \mathrm{~A}$ & $1.33 \mathrm{~B}$ \\
\hline & Atta & $0.19 \mathrm{~A}$ & $0.14 \mathrm{~A}$ & $0.04 \mathrm{~A}$ & $0.16 \mathrm{~A}$ & $0.21 \mathrm{~A}$ & $0.23 \mathrm{~A}$ \\
\hline & Olygomyermex & $0.72 \mathrm{~A}$ & $0.71 \mathrm{~A}$ & $0.09 \mathrm{~A}$ & $0.11 \mathrm{~A}$ & $2.40 \mathrm{~A}$ & $0.26 \mathrm{~A}$ \\
\hline & Cephalotes & $0.11 \mathrm{~A}$ & $0.03 \mathrm{~A}$ & $0.07 \mathrm{~A}$ & $0.11 \mathrm{~A}$ & $0.09 \mathrm{~A}$ & $0.02 \mathrm{~A}$ \\
\hline \multicolumn{8}{|c|}{ Third Collection - 72 DAS } \\
\hline \multirow[t]{2}{*}{ Ponerinae } & Hypoponera & $0.32 \mathrm{~A}$ & $0.33 \mathrm{~A}$ & $0.23 \mathrm{~A}$ & $0.35 \mathrm{~A}$ & $0.23 \mathrm{~A}$ & $0.47 \mathrm{~A}$ \\
\hline & Pachycondyla & $0.08 \mathrm{~A}$ & $0.05 \mathrm{~A}$ & $0.07 \mathrm{~A}$ & $0.04 \mathrm{~A}$ & $0.09 \mathrm{~A}$ & $0.07 \mathrm{~A}$ \\
\hline \multirow[t]{2}{*}{ Formicinae } & Camponotus & $0.00 \mathrm{~A}$ & $0.03 \mathrm{~A}$ & $0.00 \mathrm{~A}$ & $0.07 \mathrm{~A}$ & $0.00 \mathrm{~A}$ & $0.00 \mathrm{~A}$ \\
\hline & Brachymyrmex & $0.00 \mathrm{~A}$ & $0.01 \mathrm{~A}$ & $0.00 \mathrm{~A}$ & $0.01 \mathrm{~A}$ & $0.00 \mathrm{~A}$ & $0.00 \mathrm{~A}$ \\
\hline Dolichoderinae & Dorymyrmex & $0.74 \mathrm{~A}$ & $0.78 \mathrm{~A}$ & $0.64 \mathrm{~A}$ & $1.40 \mathrm{~A}$ & $0.33 \mathrm{~A}$ & $0.69 \mathrm{~A}$ \\
\hline & Tapinoma & $0.23 \mathrm{~A}$ & $0.21 \mathrm{~A}$ & $0.19 \mathrm{~A}$ & $0.11 \mathrm{~A}$ & $0.33 \mathrm{~A}$ & $0.26 \mathrm{~A}$ \\
\hline & Dolichoderus & $0.02 \mathrm{~A}$ & $0.05 \mathrm{~A}$ & $0.09 \mathrm{~A}$ & $0.02 \mathrm{~A}$ & $0.02 \mathrm{~A}$ & $0.02 \mathrm{~A}$ \\
\hline Ecitoninae & Nomamyrmex & $0.05 \mathrm{~A}$ & $0.03 \mathrm{~A}$ & $0.02 \mathrm{~A}$ & $0.02 \mathrm{~A}$ & $0.09 \mathrm{~A}$ & $0.04 \mathrm{~A}$ \\
\hline & Neivamyrmex & $0.19 \mathrm{~A}$ & $0.19 \mathrm{~A}$ & $0.19 \mathrm{~A}$ & $0.07 \mathrm{~A}$ & $0.30 \mathrm{~A}$ & $0.19 \mathrm{~A}$ \\
\hline & Eciton & $0.01 \mathrm{~A}$ & $0.02 \mathrm{~A}$ & $0.02 \mathrm{~A}$ & $0.02 \mathrm{~A}$ & $0.00 \mathrm{~A}$ & $0.02 \mathrm{~A}$ \\
\hline Myrmicinae & Solenopsis & $0.36 \mathrm{~A}$ & $0.49 \mathrm{~A}$ & $0.28 \mathrm{~A}$ & $0.26 \mathrm{~A}$ & $0.52 \mathrm{~A}$ & $0.66 \mathrm{~A}$ \\
\hline & Pheidole & $0.00 \mathrm{~A}$ & $0.02 \mathrm{~A}$ & $0.00 \mathrm{~A}$ & $0.00 \mathrm{~A}$ & $0.04 \mathrm{~A}$ & $0.00 \mathrm{~A}$ \\
\hline & Atta & $0.03 \mathrm{~A}$ & $0.08 \mathrm{~A}$ & $0.11 \mathrm{~A}$ & $0.04 \mathrm{~A}$ & $0.02 \mathrm{~A}$ & $0.04 \mathrm{~A}$ \\
\hline & Olygomyermex & $0.23 \mathrm{~A}$ & $0.49 \mathrm{~A}$ & $0.21 \mathrm{~A}$ & $0.07 \mathrm{~A}$ & $0.83 \mathrm{~A}$ & $0.35 \mathrm{~A}$ \\
\hline
\end{tabular}

*PFW: pig farming wastewater; NFR: nitrogen fertilization; DAS; days after sowing. Capital letters in the same line do not differ by the ScottKnott test at $5 \%$ probability. 
The results presented in Table 4 indicate there was no significant difference among ant genera in response to NFR in all sampling periods, showing that the distribution of the groups was independent of this factor.

Conversely, after 41 DAS, differences in the PFW factor were observed between doses of 0 and $300 \mathrm{~m}^{3} \mathrm{ha}^{-1}$ in the Myrmicinae subfamily, Solenopsis genus. The behavior of this genus differs in response to environmental quality. According to Fernandes (2003) and Nascimento, Morini, and Brandão (2001), this genus is common in disturbed areas, and adapts well to disturbed sites, justifying the increase in response to PFW at $300 \mathrm{~m}^{3} \mathrm{ha}^{-1}$ compared with the other doses. However, in a study of the myrmecofauna in a Pinus elliottii plantation, Matos et al. (1994) noted that high proportions of this group of ants occur in soils with low vegetation cover, consistent with the result of the present study at $0 \mathrm{~m}^{3}$ $\mathrm{ha}^{-1}$, with reduced vegetation cover. This is reinforced by the findings of Marinho et al. (2002), who reported that this species was among the most aggressive in the use of resources, justifying their success under these conditions. This group is also more resistant to food shortages and competes with other species of ants or other groups of animals by having an efficient mass recruitment strategy (Fowler et al. 1991).

The analysis performed at 72 DAS showed that the ant densities of the collected genera did not vary in response to the different treatments, however, a non-significant decrease in the density of the Solenopsis genus was observed in relation to the second sample. Despite this reduction, the pattern of density distribution between the different treatments remained consistent with that observed after 41 DAS; the largest average was recorded for the $300 \mathrm{~m}^{3} \mathrm{ha}^{-1}$ dose Comparing the results obtained for the group at 41 and 72 DAS with the chemical parameters of the experimental parcels (Table 1), one can suggest that the Solenopsis genus is more tolerant to the presence of heavy metals, such as copper and zinc, compared with the other groups representative of the myrmecofauna. However, the population decline observed in all groups at 72 DAS, seems to be associated with the long period of drought and consequent reduction in food availability rather than the cumulative effects of PFW on the groups.

Although the results of this study suggest that the use of PFW can induce changes in the edaphic ant community, more longer-term studies, and the use of other cultures are needed to better understand the interaction of these factors with the studied group. In this case the importance of ants as bioindicators is evident.

\section{CONCLUSIONS}

The application of PFW induced significant positive effects on the Formicidae family up to a dose of $200 \mathrm{~m}^{3} \mathrm{ha}^{-1}$; however, no effect was found on the density of organisms between the different genera.

NFR did not affect the density of the Formicidae family, or the studied genera.

These results suggest that PFW can promote changes in the edaphic myrmecofauna; however, further studies of longer duration and with other cultures should be performed to better understand the interaction of these factors with this group of organisms.

\section{REFERENCES}

ABCS - ASSOCIAÇÃO BRASILEIRA DE CRIADORES DE SUÍNOS. Manual brasileiro de boas práticas apropecuárias na produção de suínos. $1^{\text {a }}$ edição. 2011. 140p.

ABCS - ASSOCIAÇÃO BRASILEIRA DE CRIADORES DE SUÍNOS. Mapeamento da suinocultura brasielira. $2^{\text {a }}$ edição. 2016. 378p.

ALVES, M. V. et al. Macrofauna do solo influenciada pelo uso de fertilizantes químicos e dejetos de suínos no oeste do estado de Santa Catarina. Revista Brasileira de Ciência do Solo, v.32, n. 2, p. 589-598, $2008 . \quad$ Disponível

http://www.scielo.br/pdf/rbcs/v32n2/14.pdf.

Acesso em: 24 abr. 2017.

APHA - AMERICAN PUBLIC HEALTH ASSOCIATION - APHA, AWWA, WEF. Sdandard methods forthe examination of water and wastewather. Washington: American Public Health Association; 1998. 937p.

ANDERSEN, A. et al. Using ants as bioindicators in land management: simplifying assessment of ant community responses. Journal of Applied Ecology, v. 39, n.1, p.8-17, fev. 2002. Disponível em: http://onlinelibrary.wiley.com/doi/10.1046/j.13652664.2002.00704.x/full. Acesso em: 17 mar. 2017. 
BACCARO, F. B. Chave para as principais subfamílias e gêneros de formigas (Hymenoptera: Formicidae). Instituto Nacional de Pesquisas da Amazônia - INPA, Programa de Pesquisa em Biodiversidade - PPBIO, 2006. 34p.

BARETTA, D. et al. Fauna edáfica avaliada por armadilhas de catação manual afetada pelo manejo do solo na região oeste catarinense. Ciências Agroveterinárias, v. 2, n. 2, p. 97-106, 2003. Disponível em: http://revistas.udesc.br/index.php/agroveterinaria/a rticle/view/5616/3798. Acesso em: 23 marc. 2017.

BOLTON B. Taxonomic History. [Internet] 2016 [cited 2016 jan 5]: Disponível em: http://www.antweb.org/description.do?name=formi cidae\&rank $=$ family\&project $=$ allantwebants. Acesso em: 17 nov. 2016

BOLTON, B. Synopsis and classification of Formicidae. Memoirs of the American Entomological Institute, v.71, n.1, p. 1-370, 2003.

BOLTON, B. Identification guide to the ant genera of the world. Cambridge, Massachusetts: Harvardy University Press, 1994. 222 p.

BOLZANI, H. R.; OLIVEIRA, D. L. A.; LAUTENSCHLAGER, S. R. Efeito da aplicação de água residuária de suinocultura no solo e na qualidade dos seus lixiviados. Engenharia Sanitária e Ambiental, v. 17, n. 4, p. 385-392, out./dez. 2012. Disponível em: http://www.scielo.br/pdf/esa/v17n4/v17n4a05.pdf Acesso em: 27 set. 2016.

BOSCARDIN, J. et al. Efeito do fogo sobre a riqueza de formigas (Hymenoptera: Fomicidae). Ciência Florestal, v. 24, n. 4, p. 1027-1036, out./dez. 2014. Disponível

em:https://periodicos.ufsm.br/cienciaflorestal/article Lview/16616/pdf . Acesso em: 12 abr. 2017.

CAMPOS, A. T. et al. Nitrogen fertilization by deepbedding swine production and its effects on the properties of a Quartzarenic Neosol. Engenharia Agrícola, v. 32, n. 4, p. 756-764, jul./ago. 2012. Disponível http://www.scielo.br/pdf/eagri/v32n4/15.pdf Acesso em: 23 abr. 2017.
CAMPOS, A. T. et al. Nitrogen fertilization by deep bedding swine production and its effects on dry matter production and accumulation of nutrients by maize. Engenharia Agrícola, v. 33, n. 6, p. 1257-1267, nov./dez. 2013. Disponível em: http://www.scielo.br/pdf/eagri/v33n6/18.pdf.

Acesso em: 17 mar. 2017.

CAPOANE, V. et al., Transferência de nitrogênio e fósforo para águas superficiais em uma bacia hidrográfica com agricultura e produção pecuária intensiva no Sul do Brasil. Ciência Rural, v. 45, p. 647-650, 2015. Disponível em: http://www.scielo.br/pdf/cr/2014nahead/01038478-cr-00-00-cr-20140738.pdf. Acesso em: 21 abr. 2017.

CASTALDELLI, A. P. A. et al. Meso e macrofauna do solo cultivado com milho e irrigado com água residuária da suinocultura. Engenharia Agrícola, v. 35, n. 5, p. 905-917, set./out. 2015. Disponível em: http://www.scielo.br/pdf/eagri/v35n5/1809-4430eagri-35-5-0905.pdf. Acesso 23 fev. 2017.

CORDEIRO, F. C. et al. Diversidade da macrofauna invertebrada do solo como indicadora da qualidade do solo em sistema de manejo orgânico de produção. Série ciências da Vida, v. 24, n. 2, p.29-34, jul./dez. 2004.

COSTA, D. M.; CAMPOS, M. B.; MARGARIDO, L. A. C. Levantamento de Formicidae (Hymenoptera) em adubação verde: durante seu desenvolvimento e após o manejo incorporação da matéria seca ao solo. Revista Brasileira de Agroecologia, v. 9, n. 2, p. 223232, 2014. Disponível em: http://orgprints.org/27391/1/Costa Levantamento \%20de\%20Formicidae.pdf. Aceso em: 12 fev. 2017.

COUTO, P. H. M. et al. Formigas como bioindicadores da qualidade ambiental em diferentes sistemas de cultivo da soja. Revista Agrotecnologia, v. 1, p. 11-20, 2010. Disponível em: http://www.revista.ueg.br/index.php/agrotecnologia Larticle/viewFile/219/176. Acesso em: 17 mar. 2017.

CREPALDI, R. A. et al. Formigas como bioindicadores da qualidade do solo em sistema integrado lavoura-pecuária. Ciência Rural, v.44, n. 5, p. 781-787, mai. 2014. Disponível em: http://www.scielo.br/pdf/cr/v44n5/a14414cr6188.p df. Acesso em: 24 abr. 2017. 
EMBRAPA - Empresa Brasileira de Pesquisa Agropecuária. Sistema Brasileiro de Classificação de Solo. 2.ed. Rio de Janeiro, Embrapa Solos, 2006. 306 p.

FERNÁNDEZ, F.; OSPINA, M. Sinopsis de las hormigas de la región Neotropical. In: Harders FG, editor. Introducción a las hormigas de la región Neotropical. Instituto de Investigación de Recursos Biológicos Alexander Von Humbolt; p. 49-64, 2003.

FERNANDES, W. D. Biodiversidade de formigas no Pantanal sul-matogrosense. In: XVI Simpósio de Mirmecologia, 2003, Florianópolis, SC. Anais... Florianópolis: 2003. p. 7-11. CD-ROM.

FERREIRA, D. F. SisVar versão 4.2. Lavras: DEX/UFLA. 2003.

FOWLER, H. G. L. et al. Ecologia nutricional de formigas. In: PAZZINI, V. J; PARRA, R. P. Ecologia nutricional de insetos e suas implicações no manejo de pragas. São Paulo: Manole; 1991. p. 131-209.

GOLLAN, J. R. et al. Can ants be used as ecological indicators or restoration progress in dynamic environments? A case study in a revegeted riparian zone. Ecological Indicators, v. 1, n. 6, p. 1517-1525, nov. 2011. Disponível em: http://www.sciencedirect.com/science/article/pii/S 1470160X09001551. Acesso em: 24 mai. 2017.

GONZÁLEZ-VALDIVIA, N. A. et al. Mirmecofauna asociada con sistemas agroforestales en el Corredor Biológico Mesoamericano en Tabasco, México. Revista Mexicana de Biodiversidad, v. 84, n. 1, p. 306-317, ago. 2013. Disponível em: http://www.scielo.org.mx/pdf/rmbiodiv/v84n1/v84 n1a20.pdf. Acesso em: 12 mar. 2017

HOFFMANN, B. D.; ANDERSEN, A. N. Responses of ants to disturbance in Australia, with particular reference to functional groups. Austral Ecology, v. 28 n. 4, p.444-464, jul. 2003. Disponível em:http://onlinelibrary.wiley.com/doi/10.1046/j.144 2-9993.2003.01301.x/abstract. Acesso em: 23 mar. 2017.

HÖLLDOBLER, B.; WILSON, E. O. The ants. Cambridge: Belknap/Harvard University Press; 1990. 732p.
KESSLER, N. C. H. et al. Swine wastewater associated with mineral fertilization on corn crop (Zea mays). Engenharia Agrícola, v. 3, n.34, p. 554-566, mai./jun. 2014. Disponível em: http://www.scielo.br/pdf/eagri/v34n3/18.pdf.

Acesso em: 28 mar. 2017.

KESSLER, N. C. H. et al. Swine wastewater associated with mineral fertilization in soybean (Glycine $\max$ L.) Cultures: 9th production cycle. Journal of Food Agriculture and Environment, v. 11, n. 2, p. 936-942, 2013.

LACAU, L. S. R. et al. Respostas das guildas de formigas (Hymenoptera: Formicidae) a práticas silviculturais em plantio de eucaliptos. Agrotrópica, v. 20, p. 61-72, 2008. Disponível em: http://www.ceplac.gov.br/Agrotropica/vol\%2020/9. pdf. Acesso em: 14 fev. 2017.

LEAL, I. R. et al. Effects of habitat fragmentation on ant richness and functional composition in Brazilian Atlantic Forest. Biodiversity and Conservation, v. 21, n. 7, p. 687-1701, jun. 2012. Disponível em: https://link.springer.com/article/10.1007/s10531012-0271-9. Acesso em: 02. Fev. 2017.

LOBRY DE BRUYN, L. A. Ants as bioindicators of soil functions in rural environments. Agriculture, Ecosystems and Enviroment, v. 74, n. 1-3, p. 425441, jun. 1999. Disponível em: http://www.sciencedirect.com/science/article/pii/S 016788099900047X. Acesso em: 27 set. 2016.

LUCAS, S. D. M. et al. Long-term behavior of $\mathrm{Cu}$ and $\mathrm{Zn}$ in soil and leachate of na intensive no-tillage system under swine wastewater and mineral fertilization. African Journal Agriculture Reserach, v. 8, n. 7, p. 639- 647, fev.2013. Disponível em: http://www.academicjournals.org/journal/AJAR/art icle-full-text-pdf/C8692FD35376. Acesso em: 17. Nov. 2016.

MACEDO, L. P. M. Diversidade de formigas edáficas (Hymenoptera: Formicidae) em fragmentos de Mata Atlântica do Estado de São Paulo. Tese (Doutorado em Ciências) - Escola Superior de Agricultura Luiz de Queiroz, Piracicaba. Brasil. 2004. Disponível

em: http://www.teses.usp.br/teses/disponiveis/11/1114 6/tde-06052005-150803/en.php. Acesso em: 13 out. 2016. 
MAFRA, M. S. H. et al. Acúmulo de carbono em Latossolo adubado com dejeto líquido de suínos e cultivado em plantio direto. Pesquisa Agropecuária Brasileira, v. 49, n 8, p. 30-63, ago. 2014. Disponível em:

https://seer.sct.embrapa.br/index.php/pab/article/v iew/19047/12754. Acesso em: 24 abr. 2017.

MAGGI, C. F. et al. Impacts of the application of swine wastewater in percolate and in soil cultivated with soybean. Engenharia Agrícola, v. 33, n. 2, p. 279290, mar./abr. 2013. Disponível em: http://www.scielo.br/pdf/eagri/v33n2/07.pdf. Acesso em: 12 abr. 2017.

MAGGI, C. F. et al. Lixiviação de nutrientes em solo cultivado com aplicação de água residuária da suinocultura. Revista Brasileira de Engenharia Agrícola e Ambiental, v. 15, n. 2, p. 170-177, 2011. Disponível em: http://www.scielo.br/pdf/rbeaa/v15n2/v15n02a10. Acesso em: 12 fev. 2017.

MATOS, J. Z. et al. Comparação de fauna de formigas de solo em áreas de plantio de Pinus elliottii, com diferentes graus de complexidade estrutural. Biotemas, v. , n. 1-2, p. 57-64, 1994. Disponível em: https://periodicos.ufsc.br/index.php/biotemas/articl e/viewFile/22673/20638. Acesso em: 23 abr. 2017.

MARINHO, C. G. S. et al. Diversidade de formigas (Hymenoptera: Formicidae) da serapilheira em Eucaliptos (Myrtaceae) e área de cerrado de Minas Gerais. Neotropical Entomology, v. 31, n. 2, p.187195, abr./jun. 2002. Disponível em: http://www.scielo.br/pdf/ne/v31n2/a04v31n2.pdf. Acesso em: 01 mai. 2017.

MELO, L. A. S. Influência de lodos de esgoto nas populações de ácaros e colêmbolos de solo na cultura do milho. In: BETIOL, W.; CAMARGO, A. O. (Ed.). Lodo de esgoto: Impactos ambientais na agricultura. Jaguariúna: Embrapa Meio Ambiente; 2006. p. 227-234.

MENEGHETTI, A. M. et al. Foliar contents in babycorn and chemical attributes of an oxisol under application of swine wastewater. Engenharia Agrícola, v. 21, n. 6, p. 574-582, nov./dez. 2013. Disponível em:

http://www.seer.ufv.br/seer/index.php/reveng/artic le/view/410/291. Acesso em: 12 abr. 2017.
MENEGHETTI, A. M. et al. Mineral composition and growth of babycorn under swine wastewater combined with chemical fertilization. Revista Brasileira de Engenharia Agrícola e Ambiental, v. 16, n. 11, p. 1198-1205, 2012. Disponível em: http://www.scielo.br/pdf/rbeaa/v16n11/v16n11a08 .pdf. Acesso em: 03 mar. 2017.

MIRANDA, P. N. et al. Riqueza e composição de formigas como indicadores dos efeitos do manejo florestal de baixo impacto em floresta tropical no Estado do Acre. Revista Árvore, v. 37, n. 1, p. 163173, jan./fev. 2013. Disponível em: http://www.scielo.br/pdf/rarv/v37n1/v37n1a17.pdf . Acesso em: 19 mar. 2017.

NASCIMENTO, R. P.; MORINI, M. S. C.; BRANDÃO, C. R. F. Mirmecofauna do parque natural municipal da Serra do Itapety. Zona de uso intensivo. In: XV Encontro de Mirmecologia, 2001, Londrina, PR. Anais... Londrina: 2001. p. 339-341. CD-ROM.

OLIVEIRA, M. A. et al. Vegetation structure and richness: effects on ant fauna of the Amazon - Acre, Brazil (Hymenoptera: Formicidae). Sociobiology, v. 57, n. 2, p. 243-267, jan. 2011.

RAMÍREZ, M. et al. Biodiversidad de hormigas hipógeas (Hymenoptera: Formicidae) en agroecosistemas del Cerrito, Valle del Cauca. Livestock Research for Rural Development, v. 24, n. 1, 2012. Disponível em: http://www.lrrd.org/lrrd24/1/rami24015.htm. Acesso em: 16 de mar. 2017.

RIBAS, C. S. et al. Ants as indicators in Brazil: a review with suggestions to improve the use of ants in environmental monitoring programs. Psyche, p. 1-23, 2012a. Disponível em: https://www.hindawi.com/journals/psyche/2012/63 6749/. Acesso em: 17 mar. 2017.

RIBAS, C. R. et al. Ants as indicators of the success of rehabilitation efforts in deposits of gold mining tailings. Restoration Ecology, v. 20, n. 6, p.712-720, out. 2012b. Disponível em: http://onlinelibrary.wiley.com/doi/10.1111/j.1526100X.2011.00831.x. Acesso em: 13 fev. 2017. 
RIBAS, C. R. et al. Can ants be used as indicators of environment impacts caused by arsenic? Journal Insect Conservation, v. 16, n. 3, p. 413- 421, jun. 2012c. Disponível em: https://link.springer.com/article/10.1007/s10841011-9427-2. Acesso em: 23 mai. 2017.

ROCHA, W. O. et al.. Formigas (Hymenoptera: Formicidae) bioindicadoras de degradação ambiental em Poxoréu, Mato Grosso, Brasil. Floresta e Ambiente, v. 22, n. 1, p. 88-98, 2015. Disponível em: http://www.scielo.br/pdf/floram/v22n1/2179_ 8087-floram-22-1-88.pdf. Acesso em: 21 fev. 2017.

ROSADO, J. L. O. et al. Estrutura da assembleia de formigas (Hymenoptera: Formicidae) epigéicas em áreas reabilitadas após mineração de carvão a céu aberto no sul de Santa Catarina, Brasil. Revista Tecnologia e Ambiental, v. 21, p. 207-227, 2014. Disponível em: http://periodicos.unesc.net/tecnoambiente/article/v iew/1759. Acesso em: 27 mar. 2017.

SANTOS, M. P. C. J.; CARRANO-MOREIRA, A. F.; TORRES, J. B. Diversidade de formigas epigeicas (Hymenoptera: Formicidae) em floresta ombrófila densa e em cultivo de cana-de-açúcar, no município de Igarassu, PE. Revista Brasileira de Ciências Agrárias, v. 7, n. 4, p.648-656, 2012. Disponível em: http://www.redalyc.org/pdf/1190/119024993018.pd f. Acesso em: 14 fev. 2017.

SCHMIDT, F. A.; RIBAS, C. R.; SCHOEREDER, J. H. How predictable is the response of ant assemblages to natural forest recovery? Implications for their use as bioindicators. Ecological Indicators,v. 24, p. 158-166, jan. 2013. Disponível em: http://www.sciencedirect.com/science/article/pii/S 1470160X12002300. Acesso em: 19 fev. 2017.

SEGANFREDO, M. A.; SOARES, I. J.; KLEIN, C. S. Potencial fertilizante e poluente dos dejetos de suínos no contexto das pequenas propriedades do Oeste de SC. (Comunicado Técnico, 342). Concórdia, Embrapa Suínos e Aves, 2003. 4p.
SEIDEL, E. P. et al. Aplicação de dejetos de suínos na cultura do milho cultivado em sistema de plantio direto. Acta Scientiarum Technoly, v. 32, n. 2, p. 113117, 2010. Disponível em: file:///C:/Users/User/Downloads/5312-38786-1PB.pdf. Acesso em: 03 mar. 2017.

SILVA, R. F. et al. Population fluctuation in soil meso and macrofauna by the successive application of pig slurry. Revista Ciência Agronômica, v. 47, n. 2, p. 221-228, abr./jun. 2016. Disponível em: http://ccarevista.ufc.br/seer/index.php/ccarevista/a rticle/view/3825/1350. Acesso em: 11 mar. 2017.

SILVA, R. R.; BRANDÃO, C. R. F. Formigas (Hymenoptera: Formicidae) como bioindicadores de qualidade ambiental e da biodiversidade de outros invertebrados terrestres. Biotemas, v. 12, n. 2, p. 5573, 1999. Disponível em: file:///C:/Users/User/Downloads/21777-69792-2PB.pdf. Acesso em: 23 fev. 2017.

TESSARO, D. et al. Edaphic mesofauna (springtails and mites) in soil cultivates with baby corn and treates with swine wastewater combined with chemical fertilization. Journal of Food Agriculture and Environment, v. 9, n. 3-4, p. 983-987, 2011.

TESSARO, D. et al. Macrofauna of soil treated with swine wastewater combined with chemical fertilization. African Journal Agriculture Research, v. 8, n. 1, p. 86-92, jan. 2013. Disponível em: http://www.academicjournals.org/journal/AJAR/art icle-full-text-pdf/BCC95CA32784. Acesso em: 30 mar. 2017.

WINK, C. et al. Insetos edáficos como indicadores da qualidade ambiental. Revista Ciências Agroveterinárias, v.4, n. 1, p. 60-71, 2005. Disponível em:

http://revistas.udesc.br/index.php/agroveterinaria/a rticle/view/5405/3607. Acesso em: 23 fev. 2017. 